\title{
A UNIFIED MODEL OF SHARIAH INDICES FOR HUMAN DEVELOPMENT AND PROSPERITY ${ }^{1}$
}

\author{
Atiq-ur-Rehman* \\ M. Ishaq Bhatti **
}

\begin{abstract}
In recent years, several attempts have been made to measure human prosperity using shariah objectives. These, however, have failed to propose a unified model that incorporates the 'means to achieve these objectives'. This paper attempts to fill this gap by arguing that a large proportion of shariahled prosperity measures are in line with the United Nations' Millennium and Sustainable Development (MSD) goals to achieve global development targets and reduce poverty. This paper proposes a global unified model for a human development index that identifies existing development data that can be utilised in accordance with the objectives of shariah. The proposed model attempts to build a bridge between shariah-based Islamic development indices and MSD goals to achieve prosperity via religiosity.
\end{abstract}

Keywords: Objectives of shariah, development, spirituality, human prosperity.

\section{Introduction}

Recently, Kanbir and Dikkaya ${ }^{2}$ conducted an empirical study comparing 148 Muslim and non-Muslim countries using the Islamic Development Index (IDI) criteria, which averages material and spiritual values as defined under maqasid al-shari'ah. They found that the IDI ranking of Islamic countries is lower than non-Islamic states in both material and spiritual development. Among others who have attempted to develop these indices are Chapra, ${ }^{3}$ Rehman and Askari ${ }^{4}$ (see their Islamicity Index), and Rauf ${ }^{5}$ (Islamicity of nations). In general, their methods may not meet the United Nations' Millennium and Sustainable Development (MSD) requirements. In this paper, we argue that Islam is not merely a set of religious and spiritual exercises for Muslims. It is a complete code of life based on well-defined objectives relevant to the whole of humanity. Shariah ${ }^{6}$ scholars have classified these objectives into five main categories: (1) 
the Security of Din (hifz ad-din); (2) the Security of Life (hifz an-nafs); (3) the Security of Intellect (hifz al- 'aql); (4) the Security of Lineage or Posterity (hifz an-nasl); and (5) Economic Security (hifz al-mal). These five major objectives have several sub-objectives, which collectively constitute a prosperous society. Not surprisingly, the global development agenda outlined in the Millennium Development Goals (MDG) and sustainable goals declarations is only a subset of the goals specified by the shariah. Ali and Hasan (2011) examined the theoretical framework which developed a method to gauge socio-economic development in line with maqasid al-shari'ah. Their proposed measures facilitate policy guidance at various levels of aggregation in Islamic Finance (see for example Hasan et al., 2018). ${ }^{7}$

In the early days of Islam, ${ }^{8}$ Islamic scholars identified five main objectives around which the teachings of Islam revolve. These five objectives formulate such a comprehensive concept of human prosperity that all the definitions of development designed so far rarely cross the limits specified by them. Therefore, if an index of human prosperity could be made based on shariah objectives, it would be capable of subsuming most of the recently developed measures for human prosperity. Consequently, Islamic scholars have recognised the need to formulate an index of human prosperity based on the objectives of shariah. Several authors have proposed different procedures for developing a shariahbased index of development. Recent examples in the literature include, Ali and Hasan (2011), ${ }^{9}$ Ali, Tohirin and Ismail (2014), Ashraf (2016), ${ }^{10}$ Ho et al. (2014), ${ }^{11}$ Alaabed et al. (2016), ${ }^{12}$ Rusydiana and Firmansyah (2018), Hasan et al. (2018), ${ }^{13}$ Ibrahim et al. (2019), ${ }^{14}$ Alias et al. (2019), ${ }^{15} \mathrm{Al}$ Rahahleh et al. (2019), ${ }^{16}$ Cahya et al (2019) ${ }^{17}$ and Azmat et al. (2020) ${ }^{18}$ among others. However, these papers failed to develop a unified model which can incorporate the 'means' for achieving those objectives. They also did not differentiate between the 'objectives' themselves and the means/sources for achieving them. This paper attempts to fill this gap by arguing that a large proportion of shariah-led prosperity measures match the United Nations' Millennium and Sustainable Development (MSD) goals. The proposed model attempts to build a bridge between shariah-based Islamic development indices and the MSD goals to achieve prosperity via religiosity.

While those 'objectives' are recognisable by the entire globe, the 'means to achieve those objectives' are specific to Muslim societies, and are not necessarily desirable elsewhere. There are several problems with mixing the objectives with the means to achieve them, summarised as follows:

1. The final objectives that Islam wants in society are well recognised and have worldwide accept ability. But the 'means to achieve the objectives' proposed by Islamic shariah are recognised only by Muslim societies. 
2. Data on the 'means to achieve the objectives' is rarely available. Moreover, it is extremely difficult to collect data on 'means to achieve objectives'. Sometimes it is hard to get data from the Islamic world of any kind.

3. Since the 'means to achieve the objectives' given by Islam are usually not recognised by the non-Muslim world, the wider world probably cannot be convinced to collect the data on these indicators in future.

4. If data from non-Muslims could not be collected, a comparison between Muslim and non-Muslim worlds is not possible.

In the rest of this section, we attempt to explain these points with some examples. To begin, one needs to understand that the basics of the Islamic socio-economic system are designed to encourage a reduction in wealth accumulation by contributing the annual $2.5 \%$ zakah to those needy members of the community who are below the poverty line. This voluntary contribution reduces income inequality. The proposition of zakah, khairat, sadaqah and other charities are 'means' to achieve these objectives. In Qur'an 59:7, under the laws for distribution of war booty, it is stated that, "So that it (wealth) may not (make) a circuit between the rich among you."

A reduction in the concentration of wealth is also a globally recognised objective. The MDG agenda item 1A "aims at improving the share of bottom quintile in aggregated income spans around this objective." Therefore, nations across the globe, both Muslim and non-Muslim, have started collecting data on indicators of inequality, including income share of the bottom quintile and GINI index. But, as zakah is not recognised in non-Muslim societies, no data is generally obtained from the non-Muslim world on this indicator. Studies like Ali and Hassan $(2014)^{19}$ have proposed indices in which such indicators are included, but only for Muslim society. As such, these indices are incapable of providing a universally acceptable development measure or valid comparison between the Muslim and non-Muslim worlds. This study, by differentiating between 'objectives' and the 'means to achieve the objectives', proposes a number of indicators which have global acceptability and could constitute a good proxy of progress toward the objectives of shariah.

\section{Means to Achieve Objectives in the Islamic Tradition}

The 'objectives' and the 'means to achieve the objectives' are two distinct things, with the Islamic scriptures explicitly differentiate between them. For example, regarding fasting: 
Oye who believe, fasting is prescribed for you, even as it was prescribed for those before you that ye may ward off (evil). (2:183)

This verse explains that one should fast because doing so will ward off evil and achieve the objective of 'fasting'. While data on evils/crimes could easily be obtained, data on fasting would be very difficult to find.

Similarly, the objective of obligatory prayer is to prevent one from evil and vulgarness, as stated in the Qur'an:

Prayer restrains from shameful and unjust deeds. (29:45)

Vulgarness could be measured by several proxies, e.g. the percentage of unwed mothers, which is available in many countries. But the data on Salah would be difficult to obtain. Even in Muslim societies, data on the regularity of Salah is not easy to collect. This is because Islam discourages the public display of good deeds. Similarly, the Qur'an explicitly expresses the end objective of its divine order. Thus, the distinction between the objectives and the means to achieve those objectives does not fall out of the Islamic tradition.

\section{Literatures on the Objectives of Shariah}

As stated earlier, most of the literat ure that attempts to construct a development index with roots in maqasid al-shari'ah fail to differentiate between objectives and the means of achieving them. Therefore, it is very hard to construct a globally acceptable index of human development based on shariah. A selected study on this topic is Ali and Hassan (2014), ${ }^{20}$ which briefly explains the objectives of shariah and constructs an index that can measure micro-level data. The study used Pakistani survey data on zakah, prayers, and other Islamic activities as per the five pillars of Islam. However, their proposed index had limited acceptability. Similarly, Amin et al (2004) provided a very comprehensive account of the objectives of shariah and proposed several indicators that could be used to measure development in light of them. The indicators included soundness of faith and performing the five daily prayers. However, the five times daily prayers should not be a final objective, but a means of achieving the objective of encouraging the forbidding of evils and rudeness.

Recent literature lists the indicators that could be used to measure an Islamic development index (see Esen 2015). ${ }^{21}$ For example, 'expenditure on health' could be an indicator of 'security of posterity'. It is obvious, however, that the two things only have a very weak relationship. On the other hand, some 
very strong indices are often dropped from the construction of development indices. For example, 'HIV prevalence', which could indicate the occurrence of extramarital sexual relationships, is out of the index. Various authors have contributed to shariah-based indexation, for example Ali and Hasan (2011), ${ }^{22}$ Ali, Tohirin and Ismail (2014), Ashraf (2016), ${ }^{23}$ Ho et al. (2014), ${ }^{24}$ Rusydiana, A. S., \& Firmansyah, I. (2018), Hasan et al. (2018), ${ }^{25}$ Ibrahim et al. (2019), ${ }^{26}$ Alias et al. (2019) ${ }^{27}$ and Cahya et al (2019). ${ }^{28}$ However, the emphasis of these studies has been on economic security and other issues, while ignoring the main objectives of shariah. This paper fills this gap and develops a uniform shariah-based development index from the available indicators of development accepted globally.

Chapra $(2008)^{29}$ pioneered an extension of the vision of development in light of the objectives of shariah. However, his work is abstract, without concrete and 'measurable' indicators capable of measuring socio-economic variables. For example, Chapra counts qualitative values and proper motivations among the sub-objectives of 'Security of Faith', but does not give a method to measure those two variables. We need to quantify these variables in a unified modelling form practitioners can apply in real life using observed data as input for computing-based models. Our proposed unified model of human development and prosperity is a timely attempt to fill this research gap in line with UN human development goals.

Most indices in the existing literat ure are developed by economists. Certain Islamic economists have attempted to develop a measure of 'Islamicity' in the context of economic indicators. ${ }^{30}$ One of these attempts is Rehman and Askari's 2010 31 “An Economic Islamicity Index (EI2)." But the problem with these measures is that they are heavily influenced by economic aspects that undermine other objectives. The fact that economic security is counted as the last objective among the objectives of shariah makes defining development through the lens of economic indicators alone nonsensical. We need to include all the objectives.

In our view, the book Defining Islamic Statehood: Measuring and Indexing Contemporary Muslim States by Imam Feisal Abdul Rauf ${ }^{32}$ is the most successful attempt at measuring prosperity based on the objectives of shariah. Rauf has developed an excellent text derived from discussion with numerous scholars over a long period. However, the author imposes an unnecessary restriction by limiting the index only to Muslim countries; it should be possible to extend the work to non-Muslim countries as well due to the universality of Islam. As you will see in the forthcoming discussion, there is only one sub-index among the five indices and their numerous sub-indices which might not be acceptable to non-Muslims. 
The basic definition of development adopted by social scientists in the first half of the twentieth cent ury has been proven deficient. As a result, development indices are continuously expanding and becoming more comprehensive. The struggle to define human prosperity is therefore ongoing. For example, reduction of poverty is a shariah objective in which zakah and charity are central. At a global level, under the UN umbrella, nations are committed to achieving similar goals and are collecting data to monitor their progress in this area. There are other objectives not listed in the Millennium and Sustainable Development Goals that are nevertheless measures of human prosperity and many nations have systematic data on them.

\section{Objectives of Shariah and Their Measurement}

As stated earlier, the objectives of shariah are categorised into five. In this section, we briefly introduce these five objectives and the 'indicators' which can be used to measure their progress.

\section{OBJECTIVE 1 - SECURITY OF FAITH (SF)}

The objective 'security of faith' is the most important objective of shariah. It has several sub-objectives, which include (a) implementation of Islam as a religion and (b) religious freedom. The first sub-objective cannot be taken as a globally acceptable target, yet data is abundantly available by which it could be measured. The second objective is as much acceptable to non-Muslims as to Muslims. The sub-objectives and their indicators are listed below:

\section{i. SF1- People should follow Islam}

The most important aspect of shariah is religion (din). The only acceptable din on the Day of Judgment, according to shariah, is Islam. It is stated in the Qur'an (3:19) that, "No doubt, the (true) religion with Allah is Islam." Similarly, Allah said in Qur'an 3:85, "For, if one goes in search of a religion other than Islam, it will never be accepted from him, and in the life to come he shall be among the losers."

Therefore, 'security of din' primarily means the security of Islam and no other religion. The Islamic tradition envisions the entirety of mankind as Muslim. Therefore, while commanding the Muslims to perform jihad during warfare, Allah says, "And fight them until there is no temptation, (Or: discord, strife, sedition) and the religion is for Allah" (8:39).

The above verse indicates that Islam encourages continuous efforts to spread the religion until all humanity becomes 'Muslim'. 


\section{Indicator}

The progress of this objective could be measured via the percentage growth of the Muslim population. This is the only objective that might be unacceptable to the non-Muslim world as an objective of development. However, for the Muslim world, it is the most important objective.

The construction of an SF1 index is as follows:

$$
\begin{gathered}
\mathrm{PM}_{\mathrm{i}}=\text { percentage of Muslim population } \\
\mathbf{S F}_{\mathbf{i}}=\mathbf{P M}_{\mathbf{i}}
\end{gathered}
$$

The data for this indicator is available from the PEW research centre.

\section{ii. SF2 - Religious Freedom}

Even though Islam wants everyone to be Muslim, this target should not be achieved through force. Rather, the choice of religion and faith must be voluntary, without any imposition. Islam strongly prohibits forced conversion. In this regard, one can refer to the verse of the Qur' an below.

There is no compulsion in religion; truly the right way has become clearly distinct from error. $(2: 256)$

Islam is such a strong advocate of religious freedom that Prophet Muhammad said that if someone kills a non-Muslim, he will never smell the fragrance of Heaven.

The one who kills a Muaahid (non-Muslim living in an Islamic State legally) will never smell the fragrance of Heaven, even though the fragrance of (the) heavens reaches a distance of 40 years. (Ibnu Majah, Hadith No 2686)

Additionally, offences based on religion are strictly prohibited, as stated in a famous hadith:

Beware that if someone did (anything) unjust with a Muaahid, or causes him a loss, or grabs something from him without his will, I will advocate him (Muaahid) on the Day of Judgment. (Silsil Ahadith Sahiha, Hadith No 445)

Therefore, forced conversion or any other kind of unjust and indecent act imposed on people from other religions are prohibited and liable to punishment 
under shariah. Therefore, one important sub-objective of this objective of faith is to have universal religious freedom.

\section{Indicator}

Data on religious freedom for all countries is available online, for instance via the PEW Research Institute. PEW provides two measures of religious freedom: (a) Government Restriction (on religion) Index and (b) Social Hostility Index. The first measures the religious restrictions imposed by a government and its agencies, while the second measures the attitude of the public towards religious tolerance. Unfort unately, the PEW Institute has its own perspective of religious freedom which may not be acceptable to many. However, the collection of data from across the world indicates that the idea of religious freedom has worldwide acceptability; data rooted in a more reasonable definition of religious freedom could be collected without much difficulty.

The construction of an SF2 index shall be as follows:

$\mathrm{GRI}_{\mathrm{i}}=$ Government restrictions on religion index

$\mathrm{SHI}_{\mathrm{i}}=$ social hostilities index

Both of these indices are measured on a scale of 10, meaning the index is multiplied by 10 to make it comparable with the construction of other indices.

$$
S F 2_{i}=1 / 2\left(10 \times G R I_{i}+10 \times H_{S I}\right)
$$

\section{iii. Construction of Security of Faith - SF index}

The SF (security of faith index) could be constructed as a weighted average of SF1 and SF2. However, since PEW's calculations are biased toward their perception of religious freedom, a smaller weight is assigned to SF2 relative to SF1.

$$
\mathrm{SF}_{\mathrm{i}}=\alpha \mathrm{SF} 1_{\mathrm{i}}+(1-\alpha) \mathrm{SF} 2_{\mathrm{i}}
$$

Where $0<\alpha<1$, with the proposed weighting of $\alpha=0.7$.

\section{OBJECTIVE 2 - SECURITY OF LIFE (SL)}

The second most important objective in shariah is Security of Life (SL). This can take various forms, e.g. security against deadly diseases, security against killing and murders, etc. The sub-objectives of this objective are given below. 


\section{i. SL1: Security against deadly diseases and threats to life}

Islam attaches extreme importance to life security. The Qur'an says:

If anyone saves a life, it shall be as though he had saved the lives of all mankind. (5:32)

\section{Indicator}

Two indicators are proposed to measure the progress of this objective: (a) infant mortality and (b) maternal mortality. These indicators are available from the World Development Indicators Database, published by the World Bank.

The index for security against deadly diseases can be constructed as follows:

$\mathrm{MM}_{\mathrm{i}}=$ maternal mortality per thousand live births

$\mathrm{IM}_{\mathrm{i}}=$ infant mortality per thousand live births

These two factors will formulate the index for deadly diseases:

$$
\mathrm{DD}_{\mathrm{i}}=\mathbf{M M}_{\mathrm{i}}+\mathbf{I M}_{\mathrm{i}}
$$

The relative position of a country with respect to these indicators is calculated as:

$$
\mathrm{SL}_{\mathrm{i}}=100 \times \frac{\mathrm{DD}_{\mathrm{i}}^{-1}}{\max _{\mathrm{i}} \mathrm{DD}_{\mathrm{i}}^{-1}}
$$

\section{ii. SL2: Security against intentional killings, homicide and war-related deaths}

Secondly, Islam strictly forbids extrajudicial killings and those things that may threaten life.

And do not kill the soul which Allah has forbidden except for the requirements of justice; this He has enjoined you with that you may understand (6:151).

Data for this objective is also available for the entire world. Summarising the available indicators, we can construct the following:

$\mathrm{BD}_{\mathrm{i}}=$ battle related deaths per thousand

$\mathrm{H}_{\mathrm{i}}=$ intentional homicide per thousand

Therefore the indicator for murder and intentional killing shall take the following form: 


$$
\mathbf{M}_{\mathrm{i}}=\mathbf{B D}_{\mathrm{i}}+\mathbf{H}_{\mathrm{i}}
$$

The relative position of countries could be calculated as:

$$
\operatorname{SL2}_{\mathrm{i}}=100 \times \frac{M_{\mathrm{i}}^{-1}}{\max _{\mathrm{i}} M_{i}^{-1}}
$$

\section{iii. Security of Life Index}

The composite index for the security of life could be constructed by combining the above two indicators as follows:

$$
\mathrm{SL}_{\mathrm{i}}=\alpha \mathrm{SL} 1_{\mathrm{i}}+(1-\alpha) \mathrm{SL} 2_{\mathrm{i}}
$$

Where $0<\alpha<1$, here we propose $\alpha=0.5$

\section{OBJECTIVE 3 - SECURITY OF INTELLECT (SI)}

The third objective is security of intellect. The intellect means the ability and capacity to understand. The Qur'an, in a number of places, praises those who understand. The sub-objectives of this objective are listed below:

\section{i. SI1-Research and Exploration of the Creation of Allah}

For the security of intellect, Islam emphasises two things, (a) seeking knowledge and (b) researching the mysteries of the universe:

Verily! In the creation of the heavens and the earth, and in the alternation of night and day, there are indeed signs for men of understanding. Those who remember Allah (always, and in prayers) standing, sitting, and lying down on their sides, and think deeply about the creation of the heavens and the earth, (saying): "Our Lord! You have not created (all) this without purpose, glory to You! (Exalted be You above all that they associate with You as partners). Give us salvation from the torment of the Fire." (3:191)

He grants hikmah to whom He pleases, and he, to whom hikmah is granted, is indeed granted abundant good. But none remember (will receive admonition) except men of understanding. (2:269) 
These verses indicate that the intellect that leads to a better understanding of the universe is praiseworthy because such will lead to the recognition that there is a Creator who formed the universe and to whom we should surrender.

\section{Indicator}

The number of researchers engaged in $R \& D$ could be used to measure the progress of this objective. The index could be constructed as follows:

$$
\begin{gathered}
\mathrm{RD}_{\mathrm{it}}=\text { Researchers in } \mathrm{R} \& \mathrm{D} \\
\mathbf{S I 1}=\mathbf{1 0 0} \times \frac{\mathbf{R D}_{\mathbf{i}}}{\mathbf{m a x}_{\mathbf{i}} \mathbf{R D _ { \mathbf { i } }}}
\end{gathered}
$$

\section{ii. SI2- Literacy}

Islam emphasises the seeking of knowledge and education for men and women, rich and poor, young and old, all colours and creeds. Islam emphasises that knowledge leading to a better understanding of the universe will result in piety towards Allah.

\section{Indicator}

Statistics on literacy are abundantly available. The index could be constructed as follows:

$$
\begin{gathered}
\mathrm{L}_{\mathrm{i}}=\text { literacy rate, } \% \text { of the total population } \\
\mathrm{D}_{\mathrm{i}}=\text { difference in literacy rates for male and female }
\end{gathered}
$$

The difference in literacy rates for males and females should have a negative relationship with indicator SI2, whereas the aggregate literacy rate should have a positive relationship with the index:

$$
S I 2=\frac{1}{2}\left(L_{i}+100 \times \frac{D_{i}^{-1}}{\max _{i} D_{i}^{-1}}\right)
$$

\section{iii. SI3 - Security against sources of interruption in human intellect}

In addition to the above-mentioned objectives, Islam also wants to reduce sources of interruption in human intellect. Therefore, those drugs and narcotics that affect our ability to think are declared haram. 


\section{Indicator}

Consumption of alcohol, wine and other things that affect our ability to think may be used as another indicator of this objective. Data on alcohol consumption is also available from the WHO. A higher level of alcohol consumption leads to slower progress towards the security of intellect; therefore, the objective shall take the following form.

$$
\begin{gathered}
\mathrm{AL}_{\mathrm{it}}=\text { alcohol consumption per capita } \\
\quad \mathbf{S I 3}=\mathbf{1 0 0} \times \frac{\mathbf{A L}_{\mathbf{i}}^{-1}}{\max _{\mathbf{i}} \mathbf{A} \mathbf{L}_{\mathbf{i}}^{-1}}
\end{gathered}
$$

\section{iv. Security of Intellect (SI) Index}

The composite index for the security of intellect (SI index) could be constructed as follows:

$$
\mathrm{SI}_{\mathrm{i}}=\mathrm{aSI} 1_{\mathrm{i}}+\mathrm{bSI} 2_{\mathrm{i}}+(1-\mathrm{a}-\mathrm{b}) \mathrm{SI} 3_{\mathrm{i}}
$$

Where $\overline{\mathrm{a}} 0, \overline{\mathrm{b}} 0$ and $\mathrm{a}+\overline{\mathrm{b}} 1$. For simplicity, equal weight may be assigned to the three indicators,

$$
\mathrm{SI}_{\mathrm{it}}=\frac{1}{3}\left[\mathrm{SI} 1_{\mathrm{i}}+\mathrm{S} 12_{\mathrm{i}}+\mathrm{S} 13_{\mathrm{i}}\right]
$$

\section{OBJECTIVE 4 - SECURITY OF POSTERITY /LINEAGE (SP)}

In Islam, security of lineage means: (a) avoiding fulfilling sexual desire in a forbidden manner, (b) security of future generations, and (c) fulfilling sexual desire in a natural way.

\section{i. SP1-Security of Piousness}

Fulfilling sexual desire with a legitimate spouse is what Islam wants to see in society. Any sexual relationship outside of marriage brings very ill consequences to society, as is visible throughout the globe. In the United States, 50 per cent of people living under the poverty line are single mothers. The website Child Trends notes the following about unmarried mothers:

i. Children born to unmarried mothers are more likely to grow up in a 
single-parent household, experience unstable living arrangements, live in poverty, and have socio-emotional problems. As these children reach adolescence, they are more likely to have low educational attainment, engage in sex at a younger age, and have children outside marriage. As young adults, children born outside of marriage are more likely to be idle (neither in school nor employed), have lower occupational status and income, and have more troubled marriages and more divorces than those born to married parents.

ii. Women who give birth outside of marriage tend to be more disadvant aged than their married counterparts, both before and after birth. Unmarried mothers generally have lower incomes, lower education levels, and are more likely to be dependent on welfare assistance compared with married mothers. Women who have a non-marital birth also tend to fare worse than childless single women; for example, they have reduced marriage prospects compared with single women without children.

There are many verses in the Qur' an indicating the import ance of preventing such situations. Islam forbids sexual relationships outside of marriage, be it with or without consent. Sex outside marriage is one of the most heinous crimes in society, as per shariah.

Do not draw near to any unlawful sexual intercourse; surely it is a shameful, indecent thing, and an evil way (leading to individual and social corruption). (17:32)

Single and unwed mothers have become significant problems in many European and North American countries. As mentioned, 50 per cent of those individuals living under the poverty line in the United States are single mothers. The world has started recognising that single mothers are a problem; many countries now measure statistics on single mothers for this reason.

\section{Indicator}

The percentage of single mothers could be used as an indicator for the objective 'security of lineage'. Such statistics are available for many countries, although not all. Another indicator of this objective could be the prevalence of HIV in children. The prevalence of HIV in children is a direct consequence of the extramarital sexual relationships conducted by their biological parents. Data on these indicators is available via many sources, including the World Development Indicators. 
The index for objective SP1 could be constructed as follows:

$$
\begin{gathered}
\mathrm{UM}_{\mathrm{i}}=\text { percentage of unwed mothers } \\
\mathrm{HIV}_{\mathrm{i}}=\text { children with HIV per thousand }
\end{gathered}
$$

These indicators have an inverse relation with the security of lineage. The relative position of a country in these objectives could be calculated as follows:

$$
\begin{aligned}
& \mathrm{UM} 2_{\mathrm{i}}=100 \times \underset{\max _{\mathrm{i}} \mathrm{UM}_{\mathrm{i}}^{-1}}{\mathrm{UM}^{-1}} \\
& \mathrm{HIV}_{\mathrm{i}}=100 \underset{\max _{\mathrm{i}} \mathrm{HIV}_{\mathrm{i}}^{-1}}{\mathrm{HIV}_{\mathrm{i}}^{-1}} \\
& \mathrm{SP} 1_{\mathrm{i}}=\mathrm{HIV} 2_{\mathrm{i}} \text { if } \mathrm{UM} 2_{\mathrm{i}} \text { is not available } \\
& S P 1_{i}=\frac{1}{2\left(H I V 2_{i}+U M 2_{i}\right)} \text { if } U M 2_{i} \text { is available }
\end{aligned}
$$

\section{ii. SP2 - Fulfilling sexual desires in a natural way}

Islam accepts only the natural way of satisfying sexual desire. The nation of Lot was eliminated for satisfying their sexual desires through unnatural means, i.e. homosexuality. In fact, homosexuality is a curse leading to a large number of negative consequences. The Family Research Institute writes that, according to a pioneering study, 6,737 obituaries from 18 US homosexual journals were compared to a large sample of obit uaries from regular newspapers. The obit uaries from the regular newspapers were similar to US averages for longevity: the median age of death for married, never-divorced men was 75 and 80 per cent of them died old (age 65 or older). For unmarried or divorced men, the median age of death was 57 and 32 per cent of them died old. Married, never-divorced women averaged 79 at death; 85 per cent died old. Unmarried and divorced women averaged age 71 and 60 per cent of them died old. The median age of death for homosexuals, however, was virtually the same nationwide - and, overall, only about 2 per cent survived to old age. If AIDS was the listed cause of death, the median age was 39 . For the 829 gays who were listed as dying of something other than AIDS, the median age of death was 42 and 9 per cent died old. The 163 lesbians had a median age of death of 44 and 20 per cent died old.

The harm of fulfilling sexual desires beyond the limits specified by nature are appearing day-by-day, statistics reveal that of the 1.2 million people in the US living with AIDS, most are involved in homosexual practices. Islam warned about these consequences 14 centuries ago. 


\section{Indicator}

PEW's report on the worldwide acceptability of homosexual practices is called the 'Gay Travel Index'. A higher value of GTI indicates a higher acceptability of homosexuality. This index could be used to measure the position of countries on this issue.

$$
\mathrm{GTI}_{\mathrm{i}}=\text { gay travel index }
$$

The gay travel index can take both positive and negative values; therefore a relative position cannot be calculated as for the other two indices. The relative position in GTI is calculated as:

$$
S P 2_{i}=100 \times \frac{\max _{i} G T I_{i}-G T I_{i}}{\max _{i} G T I_{i}-\min _{i} G T I_{i}}
$$

Thus this index shall take the value of 100 for countries having the most favourable conditions for homosexuality and the smallest value for those countries having the least favourable conditions.

The composite index could be formulated as follows:

$$
\mathrm{SL}_{\mathrm{it}}=\alpha \mathrm{SP} 1_{\mathrm{i}}+(1-\alpha) \mathrm{SP} 2_{\mathrm{it}}
$$

Where $0<\alpha<1$. For simplification, we take $\alpha=\frac{1}{2}=0.5$ so that

$$
\mathrm{SP}_{\mathrm{i}}=\frac{1}{2}\left(\mathrm{SP}_{\mathrm{i}}+\mathrm{SP} 2_{\mathrm{i}}\right)
$$

\section{iii. Security of Posterity Index}

The composite index for security of posterity could be constructed as follows:

$$
\mathrm{SP}_{\mathrm{it}}=\alpha \mathrm{SP} 1_{\mathrm{i}}+(1-\alpha) \mathrm{SP} 2_{\mathrm{it}}
$$

Where $0<\alpha<1$. For simplification, we take $\alpha=1 / 2=0.5$ so that

$$
\mathrm{SP}_{\mathrm{i}}=\frac{1}{2}\left(\mathrm{SP}_{\mathrm{i}}+\mathrm{SP2} \mathbf{i}_{\mathrm{i}}\right.
$$




\section{OBJECTIVE 5- ECONOMIC SECURITY (SE)}

The last objective of shariah is economic security. The Quran, in many places, gives due emphasis to this objective. A better understanding of it can be achieved by focusing on several economic concepts, below.

\section{i. SE1: Income}

A variety of words have a similar meaning to income and wealth in the Qur'an, e.g. maal, mataa, fadhal, khayr, etc. The struggle for income is not prohibited and is sometimes desirable. The general guidance about wealth and income is as follows:

There is no blame on you that you should seek of the bounty of your Lord (by trading during the Hajj, but beware of preoccupation to the extent of neglecting any of the rites of the Hajj). When you press on in multitude from Arafat (after you have stayed there for some time), mention God at Masharal-Haram (al-Muzdalifah); mention Him, aware of how He has guided you, for formerly you were surely of those astray. (2:198)

\section{Indicator}

This objective could be measured through the per capita income of a country. The relative position of a country could be determined as follows:

$$
\begin{gathered}
Y_{i}=\text { per capita income of a country } \\
\text { SE } 1_{i}=\mathbf{1 0 0} \times \frac{\log \left(Y_{i}\right)}{\max _{i} \log \left(Y_{i}\right)}
\end{gathered}
$$

\section{ii. SE2: Reduction in Inequality}

Along with permission to earn material resources, Islam prohibits concentrating it without disbursing its benefits to others. This objective is explicitly stated in the Qur'anic verse:

So that wealth may not be [a benefit] going round and round among such of you as may [already] be rich. (59:7) 
Islam prohibits every kind of effort and action to store wealth so that its advantages are not widely distributed. To this end, Islam introduced the system of zakah and ushr, which automatically reduce the concentration of wealth by disbursing it. In many other places, the Qur' an forbids and counts the disadvantages of hoarding within the community.

Those who are ungenerous, and bid others to be ungenerous, and conceal whatever God has bestowed upon them out of His bounty; and so we have readied shameful suffering for all who thus deny the truth. (4:37)

This objective could be measured by the GINI index, which is available for all countries worldwide. Since the GINI index takes a higher value for countries with higher inequality, the index for inequality could be constructed as follows:

$$
\mathrm{G}_{\mathrm{i}}=\mathrm{GINI} \text { index for the country }
$$

$$
S E 2_{i}=100-G I N I
$$

\section{iii. SE 3-Reducing Poverty}

One of the prime sub-objectives of economic security is the reduction of poverty and hunger. In the Qur'an, Muslims are advised to donate to the needy and poor so that they may come out of poverty. The Qur' an also urges Muslims to donate beyond the obligatory charity (zakah and ushr):

Those who spend their possessions [for the sake of God] by night and by day, secretly and openly, shall have their reward with their Sustainer; and no fear need they have, and neither shall they grieve. $(2: 274)$

Lastly, the Qur'an urges mankind to be supportive of the deprived and poor and urges mankind to escape from depravedness:

But it was Our will to bestow Our favour upon those [very people] who were deemed [so] utterly low in the land, and to make them forerunners in faith, and to make them heirs [to Pharaoh's glory]. $(28: 5)$ 
The progress toward this sub-objective could be measured by two indicators,

$\mathrm{P}_{\mathrm{i}}=$ percentage of people living under the poverty line

$\mathrm{S}_{\mathrm{i}}=$ social contributions as a percentage of revenue

From these two indicators, the indicator for security against poverty could be constructed as:

$$
S E 3_{i}=\frac{1}{2}\left[100 \times \frac{\max _{i} P_{i}-P_{i}}{\max _{i} P_{i}-\min _{i} P_{i}}+100 \times \frac{S_{i}}{\max _{i} S_{i}}\right]
$$

\section{iv. Index for Economic Security}

The composite index for economic security could be constructed as follows:

$$
\mathrm{SE}=\mathrm{aSE}_{\mathrm{i}}+\mathrm{bSE} 2_{\mathrm{i}}+(1-\mathrm{a}-\mathrm{b}) \mathrm{SE} 3_{\mathrm{i}}
$$

Where $a>0, b>0$ and $a+b<1$

\section{Constructing an Islamic Development Index}

The composite index for the five objectives detailed above can be generalised as follows:

$$
\begin{gathered}
\text { IDI }_{\mathrm{i}}=\alpha_{1} \mathrm{SF}_{\mathrm{i}}+\alpha_{2} \mathrm{SL}_{\mathrm{i}}+\alpha_{3} \mathrm{SI}_{\mathrm{i}}+\alpha_{4} \mathrm{SP}_{\mathrm{i}}+\alpha_{5} \mathrm{SE}_{\mathrm{i}} \\
\text { Such that } \operatorname{sum}_{\mathrm{i}}\left(\alpha_{\mathrm{i}}\right)=1, \alpha_{\mathrm{i}}>0
\end{gathered}
$$

Since Islam gives different priorities to these indices, with security of faith (SF) taking the highest priority, followed by security of life (SL), security of intellect (SI), security of posterity (SP) and economic security (SE), the coefficients $\alpha_{1}$ should be adjusted in a manner that reflects these priorities. Thus, the co-efficients $I$ are assigned keeping in view the following considerations:

$$
\boldsymbol{\alpha}_{1}>\boldsymbol{\alpha}_{2}>\ldots . . .>\boldsymbol{\alpha}_{5}
$$

It is important that none of these indices should have a very small weightage, entailing the following restriction:

$$
\min \alpha_{i} \geq 0.1 \text { and } \max \alpha_{i} \leq 0.3
$$


Thus, a weighting scheme satisfying the above-mentioned criteria is as follows:

$$
a_{i}=0.3-0.05_{i}
$$

Using this weighting scheme, one can easily construct the IDI for $\mathrm{i}=1,2,3$, 4, 5 as follows:

$$
\mathrm{IDI}_{\mathrm{i}}=0.30 \mathrm{SF}_{\mathrm{i}}+0.25 \mathrm{SL}_{\mathrm{i}}+0.20 \mathrm{SI}_{\mathrm{i}}+0.15 \mathrm{SP}_{\mathrm{i}}+0.10 \mathrm{SE}_{\mathrm{i}}
$$

\section{Conclusion and Policy Recommendations}

This paper distinguishes between objectives and the means to achieve them. When it comes to final objectives, these are classified as objectives of shariah which have good global acceptability and applicability. One sub-objective of 'security of faith', however, may not have global acceptability, but the other sub-objectives of the same objective do. For example, the concept of 'religious freedom' inherent in the Qur' an is globally accepted, at least theoretically. Since the objectives of shariah match with global objectives, there is no problem obtaining data on these indicators and constructing an index of development rooted in the objectives of shariah. This paper identifies the indicators that could be used to construct such an index of development.

- Further study on human development index based on maqasid alshari'ah is required by analysing the current trend of Sustainable Development Goals (SDGs), which are rapidly becoming integrated into global action on socioeconomic, political, environmental, and well-being issues. Big Data and Artificial Intelligence can be used to serve this purpose.

- Establishing the maqasidic principle as a quantitative concept is challenging since human development and prosperity may be understood in multiple dimensions. As a result, the Islamic Development Index should be assessed on a regular basis by evaluating a wider spectrum of indicators.

- 'Security of faith' may not be well received on a global scale due to misinterpretation and Islamophobia, but other objectives share the same values as the global aspiration. As a result, future human development indicators should include data and statistics from non-Muslim countries in addition to Muslim countries. 


\begin{tabular}{|c|c|c|c|}
\hline Objective & Sub-objective & Indicator & Data Source \\
\hline \multirow{3}{*}{$\begin{array}{c}\text { Objective } 1 \\
\text { SF: Security of Faith }\end{array}$} & $\begin{array}{l}\text { SF1: People should } \\
\text { follows Islam }\end{array}$ & $\begin{array}{l}\text { Percentage of Muslim } \\
\text { Population }\end{array}$ & PEW Research Institute \\
\hline & \multirow[t]{2}{*}{ SF2: Religious Freedom } & $\begin{array}{l}\text { Government Restriction } \\
\text { index }\end{array}$ & PEW Research Institute \\
\hline & & Social Hostilities Index & PEW Research Institute \\
\hline \multirow{4}{*}{$\begin{array}{c}\text { Objective 2: } \\
\text { SL: Security of Life }\end{array}$} & \multirow[t]{2}{*}{$\begin{array}{l}\text { SL1: Security against } \\
\text { deadly diseases }\end{array}$} & Maternal mortality & $\begin{array}{l}\text { World Development } \\
\text { Indicators }\end{array}$ \\
\hline & & Children mortality & $\begin{array}{l}\text { World Development } \\
\text { Indicators }\end{array}$ \\
\hline & \multirow[t]{2}{*}{$\begin{array}{l}\text { SL2: Security against } \\
\text { murder and killing }\end{array}$} & Battle Related Deaths & $\begin{array}{l}\text { World Development } \\
\text { Indicators }\end{array}$ \\
\hline & & Intentional homicide & $\begin{array}{l}\text { World Development } \\
\text { Indicators }\end{array}$ \\
\hline \multirow{4}{*}{$\begin{array}{l}\text { Objective 3: } \\
\text { SI: Security of } \\
\text { Intellect }\end{array}$} & $\begin{array}{l}\text { SI1: Research and } \\
\text { Exploration of the } \\
\text { Creation of Allah }\end{array}$ & $\begin{array}{l}\text { Researcher in } R \& D \text { per } \\
\text { million population }\end{array}$ & $\begin{array}{l}\text { World Development } \\
\text { Indicators }\end{array}$ \\
\hline & \multirow[t]{2}{*}{ SI2: Literacy } & Literacy Rate adult total & $\begin{array}{l}\text { World Development } \\
\text { Indicators }\end{array}$ \\
\hline & & $\begin{array}{l}\text { Difference between } \\
\text { literacy rate for male } \\
\text { and female }\end{array}$ & $\begin{array}{l}\text { World Development } \\
\text { Indicators }\end{array}$ \\
\hline & $\begin{array}{l}\text { SI3: Security against } \\
\text { sources of interruption in } \\
\text { human intellect }\end{array}$ & $\begin{array}{l}\text { Per capita alcohol } \\
\text { consumption }\end{array}$ & $\begin{array}{l}\text { World Health } \\
\text { Organization Report }\end{array}$ \\
\hline \multirow[t]{3}{*}{$\begin{array}{l}\text { Objective 4: } \\
\text { SP: Security of } \\
\text { posterity }\end{array}$} & \multirow[t]{2}{*}{$\begin{array}{l}\text { SP1: Security of } \\
\text { piousness }\end{array}$} & $\begin{array}{l}\text { Percentage of unwed } \\
\text { mothers }\end{array}$ & $\begin{array}{l}\text { US Department } \\
\text { for Health and } \\
\text { Demographic Statistics }\end{array}$ \\
\hline & & $\begin{array}{l}\text { Children (0-14) living } \\
\text { with HIV }\end{array}$ & $\begin{array}{l}\text { World Development } \\
\text { Indicators }\end{array}$ \\
\hline & $\begin{array}{l}\text { SP2: Fulfilling sexual } \\
\text { desires in natural way }\end{array}$ & Gay travel index & PEW Research Institute \\
\hline \multirow{4}{*}{$\begin{array}{l}\text { Objective 5: } \\
\text { SE: Economic } \\
\text { security }\end{array}$} & SE1: Income & $\begin{array}{l}\text { Per capita income } \\
\text { (constant, US\$) }\end{array}$ & $\begin{array}{l}\text { World Development } \\
\text { Indicators }\end{array}$ \\
\hline & $\begin{array}{l}\text { SE2: Reduction in } \\
\text { Inequality }\end{array}$ & GINI index & $\begin{array}{l}\text { World development } \\
\text { Indicators }\end{array}$ \\
\hline & \multirow[t]{2}{*}{$\begin{array}{l}\text { SE3: Reduction in } \\
\text { poverty }\end{array}$} & $\begin{array}{l}\text { Percentage of people } \\
\text { under } \$ 1.25 \text { poverty } \\
\text { line }\end{array}$ & $\begin{array}{l}\text { World development } \\
\text { Indicators }\end{array}$ \\
\hline & & $\begin{array}{l}\text { Social contribution as a } \\
\text { percentage of revenue }\end{array}$ & $\begin{array}{l}\text { World development } \\
\text { Indicators }\end{array}$ \\
\hline
\end{tabular}

Table 1: Indicators Proposed for Constructing Islamic Development Index Along with their Sources 


\section{Notes}

* Atiq-ur Rehman, Department of Econometrics and Statistics, Pakistan Institute of Development Economics, Islamabad, and Azad Kashmir. E-mail: atiq@pide. org.pk

** M. Ishaq Bhatti, Department of Economics and Finance, La Trobe University, Melbourne, Australia.E-mail: i.bhatti@latrobe.edu.au.

1. We are thankful to the editor, anonymous referees and Daud Batchelor for constructive comments on earlier versions of this paper. The second author acknowledges the comments and hospitality of: Hussain Qadri of Minhaj University, Lahore; Duc Nguyen of IPAG Business School, Paris; and Ian Alam of SUNY, Geneseo, USA, where the final version of this paper was completed. We take sole responsibility for any errors.

2. Ozgur Kanbir and Mehmet Dikkaya, 'Islamic Development Index,' Sosyoekonomi 29 no. 49 (2021): 151-80.

3. Muhammad Umer Chapra, Shiraz Khan and Anas Al Shaikh-Ali, The Islamic Vision of Development in the Light of Maqasid al-Shariah (London: International Institute of Islamic Thought, 2008).

4. Scheherazade S. Rehman and Hossein Askari, 'An Economic Islamicity Index (EI2),' Global Economy Journal 10, no. 3 (2010).

5. Feisal Abdul Rauf, Defining Islamic Statehood: Measuring And Indexing Contemporary Muslim States (New York: Springer, 2015).

6. Shariah is the sacred law of Islam. It is derived from the Qur'an, the Sunnah (sayings and deeds of the Prophet Muhammad), Ijma' (consensus), Qiyas (reasoning by analogy) and Maslaha (consideration of public good or common need).

7. Hamid Hasan, Salman Syed Ali, and Malik Muhammad, 'Towards a Maqasid al-Shari'ah Based Development Index,' Journal of Islamic Business and Management 8 no. 1 (2018): 20-36.

8. The period starts from the time of the Prophet Muhammad (570-632 C.E) until the Umayyad and Abbasid eras (661-1258).

9. Salman Syed Ali and Hamid Hasan, 'Towards a Maqasid al-Shariah Based Development Index Measurement,' (working paper, The Islamic Research and Teaching Institute (IRTI), Jeddah, January 19, 2014).

10. Dawood Ashraf, 'Does Shari'ah Screening Cause Abnormal Returns? Empirical Evidence from Islamic Equity Indices,' Journal of Business Ethics 134 no. 2 (2016): 209-28.

11. Catherine Soke Fun Ho, Nurul Afiqah Abd Rahman, Noor Hafizha Muhamad Yusuf and Zaminor Zamzamin, 'Performance of Global Islamic Versus Conventional Share Indices: International Evidence,' Pacific-Basin Finance Journal 28 (2014): 110-21.

12. Alaa Alaabed, Hossein Askari, Zamir Iqbal and Adam Ng, 'Benchmarking Objectives of Shari'ah (Islamic law): Index and Its Performance in Selected OIC Countries,' International Journal of Pluralism and Economics Education 7 no. 3 (2016): 218-53. 
13. Hasan, 'Towards a Maqasid al-Shariah Based Development Index.'

14. Ibrahim, Abdul Halim, Noor Naemah Abdul Rahman, Shaikh Mohd Saifuddeen and Madiha Baharuddin, 'Maqasid al-Shariah Based Islamic Bioethics: A Comprehensive Approach,' Journal of Bioethical Inquiry 16, no. 3 (2019):1-13.

15. Raja Madihah Raja Alias, Norhashiman Mohd Yasin, Badruddin $\mathrm{Hj}$ Ibrahim and Mohd Yazid Zul Kepli, 'Combating Money Laundering and Terrorism Financing: Perspectives from Maqasid al-Shariah,' in Emerging Issues in Islamic Finance Law and Practice in Malaysia, ed. Umar A. Oseni, M. Kabir Hassan, Rusni Hassan (Bingley: Emerald Publishing Limited, 2019), 129-44.

16. Fadillah Mansor, Naseem Al Rahahleh, and M. Ishaq Bhatti, 'New Evidence on Fund Performance in Extreme Events,' International Journal of Managerial Finance 15 no. 4 (2019): 511-32.

17. Bayu Tri Cahya, Umi Hanifah, Muslim Marpaung and Irma Suryani Lubis, 'The Development of Islamic Social Reporting as a Concept of Social Accountability Based on Sharia,' KnE Social Sciences (2019): 97-110.

18. Azmat, Saad, A. S. M. Sohel Azad, M. Ishaq Bhatti and Hamza Ghaffar, 'Islamic Banking, Costly Religiosity, and Competition,' Journal of Financial Research 43 no. 2 (2020): 263-303.

19. Ali, 'Towards a Maqasid al-Shariah Based Development Index.'

20. Ibid.

21. M. Fevzi Esen, 'A Statistical Framework on Identification of Maqasid al-Shariah Variables for Socio-Economic Development Index,' Journal of Business Studies Quarterly 7, no. 1 (2015): 107.

22. Ali, 'Towards a Maqasid al-Shariah Based Development Index.'

23. Asharaf, 'Does Shari'ah Screening Cause Abnormal Returns?'

24. Ho, 'Performance of Global Islamic Versus Conventional Share Indices.'

25. Hasan, 'Towards a Maqasid al-Shariah Based Development Index.'

26. Ibrahim, 'Maqasid al-Shariah Based Islamic Bioethics: A Comprehensive Approach.'

27. Alias, 'Combating Money Laundering and Terrorism Financing.'

28. Cahya, 'The Development of Islamic Social Reporting as a Concept of Social Accountability.'

29. Chapra, The Islamic Vision of Development in the Light of Maqasid Al-Shariah.

30. For religiosity measurement using a mechanism design approach, see Basov and Bhatti and Azmat et al.

31. Rehman, 'An Economic IslamicityIndex (EI2).'

32. Rauf, Defining Islamic Statehood.

\section{Bibliography}

Alaabed, Alaa, Hossein Askari, Zamir Iqbal and Adam Ng. 'Benchmarking Objectives of Shari'ah (Islamic Law): Index and Its Performance in Select OIC Countries.' International Journal of Pluralism and Economics Education 7 no. 3 (2016): 218-53. 
Ali, Salman Syed and Hamid Hasan. 'Towards a Maqasid al-Shariah Based Development Index. Measurement.' Working paper, The Islamic Research and Teaching Institute (IRTI), Jeddah, January 19, 2014.

Alias, Raja Madihah R., Norhashiman Mohd Yasin, Badruddin Hj Ibrahim and Mohd Yazid Zul Kepli. 'Combating Money Laundering and Terrorism Financing: Perspectives from Maqasid al-Shariah.' In Emerging Issues in Islamic Finance Law and Practice in Malaysia. Edited by Umar A. Oseni, M. Kabir Hassan, Rusni Hassan. Bingley: Emerald Publishing Limited, 2019.

Ashraf, Dawood. 'Does Shari'ah Screening Cause Abnormal Returns? Empirical Evidence from Islamic Equity Indices.' Journal of Business Ethics 134 no. 2 (2016): 209-28.

Azmat, Saad, A. S. M. Sohel Azad, M. Ishaq Bhatti, and Hamza Ghaffar. 'Islamic Banking, Costly Religiosity, and Competition.' Journal of Financial Research 43 no. 2 (2020): 263-303.

Bhatti, M. Ishaq and Suren Basov. Islamic Finance in the Light of Modern Economic Theory. London: Springer, 2016.

Cahya, Bayu Tri, Umi Hanifah, Muslim Marpaung and Irma Suryani Lubis. 'The Development of Islamic Social Reporting as a Concept of Social Accountability Based on Sharia.' KnE Social Sciences (2019): 97-110.

Chapra, Muhammad Umer, Shiraz Khan and Anas Al Shaikh-Ali. The Islamic Vision of Development in the Light of Maqasid al-Shariah. London: International Institute of Islamic Thought, 2008.

Esen, M. Fevzi. 'A Statistical Framework on Identification of Maqasid al-Shari ah Variables for Socio-Economic Development Index.' Journal of Business Studies Quarterly 7, no. 1 (2015): 107.

Hasan, Hamid, Salman Syed Ali, and Malik Muhammad. 'Towards a Maqasid al-Shariah Based Development Index.' Journal of Islamic Business and Management 8 no. 1 (2018): 20-36.

Ho, Catherine Soke F., Nurul Afiqah Abd Rahman, Noor Hafizha Muhamad Yusuf and Zaminor Zamzamin. 'Performance of Global Islamic Versus Conventional Share Indices: International Evidence.' Pacific-Basin Finance Journal 28 (2014): 110-21.

Ibrahim, Abdul Halim, Noor Naemah Abdul Rahman, Shaikh Mohd Saifuddeen and Madiha Baharuddin. 'Maqasid al-Shariah Based Islamic Bioethics: A Comprehensive Approach,' Journal of Bioethical Inquiry 16, no. 3 (2019):1-13.

Kanbir, Ozgur and Mehmet Dikkaya. 'Islamic Development Index'. Sosyoekonomi 29 no. 49 (2021): 151-80.

Mansor, Fadillah, Muhammad Ishaq Bhatti, Rahman, Shafiqur, and Do Hung Quang. 'The Investment Performance of Ethical Equity Funds in Malaysia.' Journal of Risk and Financial Management 13 no. 9 (2020): 219. 
Mansor, Fadillah, Naseem Al Rahahleh, M. Ishaq Bhatti. 'New Evidence on Fund Performance in Extreme Events.' International Journal of Managerial Finance 15 no. 4 (2019): 511-32.

Rauf, Feisal Abdul. Defining Islamic Statehood: Measuring and Indexing Contemporary Muslim States. New York: Springer, 2015.

Rehman, Scheherazade S. and Hossein Askari. 'How Islamic are Islamic Countries?' Global Economy Journal 10 no. 2 (2010).

Rehman, Scheherazade S. and Hossein Askari. 'An Economic Islamicity Index (EI2).' Global Economy Journal 10, no. 3 (2010). 